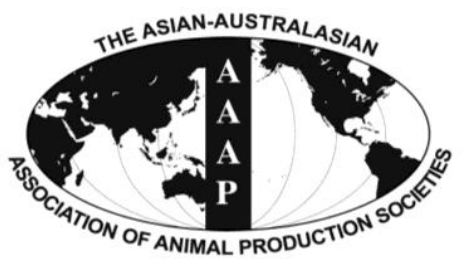

Asian-Aust. J. Anim. Sci.

Vol. 25, No. 4 : 479 - 485

April 2012

www.ajas.info

http://dx.doi.org/10.5713/ajas.2011.11435

\title{
Improvement of Fermentation and Nutritive Quality of Straw-grass Silage by Inclusion of Wet Hulless-barley Distillers' Grains in Tibet
}

\author{
Xianjun Yuan, Chengqun Yu${ }^{1}$, M. Shimojo ${ }^{2}$ and Tao Shao* \\ Institute of Ensiling and Processing of Grass, College of Animal Sciences and Technology, \\ Nanjing Agricultural University, Weigang 1, Nanjing, 210095, China
}

\begin{abstract}
In order to develop methods that would enlarge the feed resources in Tibet, mixtures of hulless-barley straw and tall fescue were ensiled with four levels $(0,10 \%, 20 \%$, and $30 \%$ of fresh weight) of wet hulless-barley distillers' grains (WHDG). The silos were opened after 7, 14 or $30 \mathrm{~d}$ of ensiling, and the fermentation characteristics and nutritive quality of the silages were analyzed. WHDG addition significantly improved fermentation quality, as indicated by the faster decline of $\mathrm{pH}$, rapid accumulation of lactic acid (LA) $(\mathrm{p}<0.05)$, and lower butyric acid content and ammonia-N/total $\mathrm{N}(\mathrm{p}<0.05)$ as compared with the control. These results indicated that WHDG additions not only effectively inhibited the activity of aerobic bacteria, but also resulted in faster and greatly enhanced LA production and $\mathrm{pH}$ value decline, which restricted activity of undesirable bacteria, resulting in more residual water soluble carbohydrates (WSC) in the silages. The protein content of WHDG-containing silages were significantly higher $(\mathrm{p}<0.05)$ higher than that of the control. In conclusion, the addition of WHDG increased the fermentation and nutritive quality of straw-grass silage, and this effect was more marked when the inclusion rate of WHDG was greater than 20\%. (Key Words : Wet Hulless-barley Distillers' Grains, Hullessbarley Straw, Tall Fescue, Mixed Silage, Fermentation Quality)
\end{abstract}

\section{INTRODUCTION}

The Tibetan plateau located in southwest China and other countries with an average altitude of over 4,000 m (Duan et al., 2008), is regarded as the Earth's third pole and the highest unique territorial unit in the world, thus, its climate and natural environment are inherently extreme and instable. The cold and arid continental climates and short growing seasons are considered to be the most important limiting factors for forage production. Due to seasonal changes throughout the year, the shortage of feedstuffs has resulted in the fluctuation in animal production and therefore most of Tibet's yak farmers feed their cows with

\footnotetext{
* Corresponding Author : Tao Shao. Tel : +86-025-84396356, Fax : +86-025-84396356, E-mail : taoshaolan@yahoo.com.cn

1 Institute of Geographic Sciences and Natural Resources Research, Chinese Academy of Sciences, Beijing 100101, China.

${ }^{2}$ Laboratory of Animal Feed Science, Division of Animal Science, Department of Animal and Marine Bioresource Sciences, Faculty of Agriculture, Kyushu University, Fukuoka 812-8581, Japan.

Submitted Nov. 18, 2011; Accepted Dec. 27, 2011; Revised Jan. 8, 2012
}

agricultural by-products (mainly various straws) during the cool/cold season. However, the use of such straws has limitations due to their low nutritive value indicated by their high cellulose, hemicellulose and lignin contents, and their low protein content and digestibility. Many methods including alkali treatment, radiation, grinding, and pelleting have been used to exploit the nutrient utilization of poor quality roughages, but being expensive and difficult to apply, are not likely to be acceptable to small-holder dairy farmers in Tibet. Ensiling could be a better option for forage production, as it not only could improve nutritive value of straws, but could also facilitate year-round fodder provision and avoid nutrition loss (Titterton and Maasdorp, 1997).

Straws are too low in water soluble carbohydrates (WSC) for extensive fermentation to produce wellpreserved silage (McDonald et al., 1991). Recently, rice straw and sugar-rich materials have been used as dairy cattle feed in the form of roughage mixtures (Suksombat, 2004). Supplement or ensiling with other palatable materials, especially green forages or agroindustrial byproducts, has been used in many developed countries in Asia for improving the available nutritients for maintenance 
of animals. Ensiling has been found to enhance fermentation quality and to produce a maintenance diet for rams or cattle (Cao et al., 2011; Ridla and Uchida, 1994). In our previous studies, it was found that ensiling straw with grass slightly increased the moisture content and main fermentation substrates such as WSC, which are generally high in tall fescue.

In the Tibetan plateau, the history of making and drinking barley wine dates back several thousand years, and there is a substantial amount of wet hulless-barley distillers' grains (WHDG) produced annually leading to an ever increasing interest in the efficient use of these WHDG due to economic and environmental concerns. WHDG usually have a low crude fiber, high crude protein and high digestibility, but high water content limits the length of storage. Because of storage problems, WHDG is often dried, however, artificial drying increases the price of WHDG substantially. Hence, most of WHDG are discarded or fresh fed for limited periods of time in Tibet. Previous researchers reported that combining and ensiling wet brewers grains (by-product very similar to WHDG) with drier feedstuffs improved its digestibility and aerobic stability compared with wet brewers grains ensiled alone (Anderson et al., 2009; Nishino et al., 2003). Ridla and Uchida (1994) reported that ensiling barley straw with wet brewers' grains improved the fermentation quality and nutritive value of the mixture. Chiou et al. (2000) found that adding wet sorghum distillers' grains to napiergrass silage improved the fermentation quality and produced a higher Flieg score. However, there is limited information regarding the effects of WHDG addition to mixed silage, especially in Tibet.

In our previous studies, the optimum straw-grass ratio was investigated by adding tall fescue to hulless-barley straw in varying proportions, increasing from 10 to $80 \%$. The results indicated that the proportion of tall fescue should be at least $40 \%$. The present experiment was intended to evaluate the effects of WHDG on the fermentation characteristics and nutritive value of strawgrass mixed silage. The aim was to preserve a forage resource in the crop harvest season by incorporating WHDG to establish a total forage programme for yak farmers in Tibet.

\section{MATERIALS AND METHODS}

\section{Silage making}

The hulless-barley (Hordeum vulgare) and tall fescue (Festuca arundinacea) were cultivated in the experimental field of the Grassland Station of Rikaze, Tibet. Both of these crops were harvested by hand on 27 Sep, 2009; the tall fescue was at the heading stage of growth. Hullessbarley straw and tall fescue were collected and chopped into approximately $2 \mathrm{~cm}$ lengths by a forage chopper and immediately transported to the laboratory. WHDG was obtained from a private barley wine processing company at Rikaze, Tibet in China and subjected to mixed silages preparation on the same day of production.

Hulless-barley straw and tall fescue were mixed in the proportions of 40/60 (wet weight), and WHDG (0, 10\%, $20 \%$ or $30 \%$ wet basis) was added to the mixed silage. After a thorough mixing, $70 \mathrm{~g}$ of the mixture was packed into a laboratory silo (110 $\mathrm{ml}$ capacity), followed by being sealed with a screw top and kept at the ambient temperature. Triplicates silos were made for each treatment and each sampling day. The silos for each mixture were opened on 7 , 14 and $30 \mathrm{~d}$ after ensiling.

\section{Chemical analyses}

Samples of hulless-barley straw, tall fescue and wet hulless-barley distiller's grains were taken before ensiling for determination of dry matter (DM), water soluble carbohydrate (WSC), crude protein (CP), neutral detergent fiber (NDF) and acid detergent fiber (ADF). After the silos were opened, the contents were mixed thoroughly, a $35 \mathrm{~g}$ sample was taken from each silo. Seventy $\mathrm{g}$ of distilled water was added to the $35 \mathrm{~g}$ sample and left at $4{ }^{\circ} \mathrm{C}$ for $24 \mathrm{~h}$, the extracts were then filtered through double-layered cheesecloth and a filter paper (Xinhua Co, China). The filtrates were used for determining $\mathrm{pH}$, ammonia-N (AN), lactic acid (LA) and volatile fatty acids (VFAs) concentrations. The $\mathrm{pH}$ of the silage was measured with a glass electrode $\mathrm{pH}$ meter (HANNA pH 211, Hanna Instruments Italia Srl, Italy). The LA was determined by the method of Barker and Summerson (1941). VFAs were determined with gas chromatography (Shimadzu GC-17A, Japan, with $12 \mathrm{~m}$ capillary column, condition: column temperature $130^{\circ} \mathrm{C}$, injection temperature $220^{\circ} \mathrm{C}$ ). Ammonia-N was determined using the phenol-hypochlorite reaction method (Broderick and Kang, 1980). The DM contents of the fresh material and silages were determined by drying in an oven at $65^{\circ} \mathrm{C}$ for at least $48 \mathrm{~h}$ (AOAC, 1984). Total nitrogen (TN) was analyzed by the Kjeldahl procedure (Krishnamoorthy et al., 1982), CP was determined as the TN multiplied by 6.25 . The WSC contents were determined by colorimetric after reaction with anthrone reagent (Thomas, 1977). The contents of NDF and ADF were determined according to Van Soest et al. (1991).

\section{Statistical analyses}

The statistical analysis included two-way analysis of variance with additive and storage periods as factors and Fisher's least significant difference test. These were performed using the GLM procedure of SAS, with the level of statistical significance preset at $\mathrm{p}<0.05$ (SAS, 1999). 
Table 1. Chemical composition of hulless-barley straw, tall fescue and wet hulless-barley distillers' grains before being ensiled

\begin{tabular}{lccccc}
\hline Ensilage materials & $\begin{array}{c}\text { Dry matter } \\
(\mathrm{g} / \mathrm{kg} \mathrm{FW})\end{array}$ & $\begin{array}{c}\text { Crude protein } \\
(\mathrm{g} / \mathrm{kg} \mathrm{DM})\end{array}$ & $\begin{array}{c}\text { WSC } \\
(\mathrm{g} / \mathrm{kg} \mathrm{DM})\end{array}$ & $\begin{array}{c}\text { NDF } \\
(\mathrm{g} / \mathrm{kg} \mathrm{DM})\end{array}$ & $\begin{array}{c}\text { ADF } \\
(\mathrm{g} / \mathrm{kg} \mathrm{DM})\end{array}$ \\
\hline Hulless-barley straw & 353.38 & 134.10 & 102.68 & 513.02 & 270.55 \\
Tall fescue & 337.83 & 57.19 & 263.32 & 477.61 & 264.21 \\
Wet hulless-barley distillers' grains & 155.86 & 259.47 & 92.21 & 438.21 & 107.94 \\
\hline
\end{tabular}

FW $=$ Fresh weight, $\mathrm{WSC}=$ Water soluble carbohydrate, $\mathrm{NDF}=$ Neutral detergent fiber, $\mathrm{ADF}=$ Acid detergent fiber.

\section{RESULTS}

The chemical compositions of hulless-barley straw, tall fescue and WHDG before ensiling are presented in Table 1. WHDG was high in CP and low in DM, NDF and ADF. The WSC content of tall fescue was relatively high compared to the hulless-barley straw and WHDG.

Changes in $\mathrm{pH}, \mathrm{DM}$ and LA contents of silages are presented in Table 2. The fermentation was more pronounced up to $\mathrm{d} 7$ and then it slowed down in all the WDHG addition treatments. All WHDG addition silages showed basically a similar $\mathrm{pH}$ profile, which was significantly lower than that of the control $(\mathrm{p}<0.05)$. The $\mathrm{pH}$ value tended to decrease with increasing inclusion of WHDG ( $>>0.05$ ), silage containing 30\% WHDG had the lowest $\mathrm{pH}$ value (4.19), whereas that of the control was still 4.88 after $30 \mathrm{~d}$ of ensiling. LA was produced rapidly during the first $7 \mathrm{~d}$ in WHDG addition silages, with the LA content was more than double that of the control silage, and this difference was maintained up to $30 \mathrm{~d}$ of ensiling $(\mathrm{p}<0.05)$. The highest LA content was observed in the silages with $20 \%$ WHDG inclusion. The DM content decreased as the rate of inclusion of WHDG increased $(\mathrm{p}<0.05)$, and decreased slightly $(p>0.05)$ from the 7 th $d$ of ensiling, reaching the lowest $(\mathrm{p}<0.05)$ at the end of ensiling (d 30).

Acetic acid (AA) concentration increased gradually in all silages during the ensiling period (Table 3). WHDG addition silages showed somewhat $(\mathrm{p}>0.05)$ or significantly $(\mathrm{p}<0.05)$ higher AA content than the control, and the silage inclusion with 10\% WHDG had the highest AA concentration during the full fermentation course. Changes in the total VFAs concentration showed a similar trend to the AA concentrations. Propionic acid and butyric acid concentrations tended to increase with prolonged storage, and were significantly $(\mathrm{p}<0.05)$ lower in silages containing WHDG as compared to the control (Table 3). The ratio of LA/AA in WHDG-containing silages reached a peak on day 7 of ensiling, and then gradually decreased until the end of the ensiling period ( $d$ 30). In contrast, the ratio of LA/AA in the control silage increased during the ensiling period and by the end of the ensiling period (d 30) was significantly $(p<0.05)$ higher as compared to the WHDG-containing silages.

The ratio of AN/TN slightly increased ( $p>0.05$ ) during the first $14 \mathrm{~d}$ of ensiling and then significantly increased $(\mathrm{p}<0.05)$ at $30 \mathrm{~d}$ of ensiling (Table 4). The ratio of AN/TN in the control silage (163.88) was nearly three times that of the WHDG-containing silages at d 7 of ensiling and this difference was maintained for the rest of the duration of the ensiling period $(p<0.05)$. The residual WSC decreased $(\mathrm{p}<0.05)$ over the first $14 \mathrm{~d}$ of ensiling from the original values of fresh forage, and then slowly declined until the end of the ensiling period (Table 4). At the 7 th $d$ of ensiling the control silage showed significantly $(p<0.05)$ higher

Table 2. Effect of adding WHDG on pH, DM and LA content of mixed silage of hulless-barley straw and tall fescue during ensiling

\begin{tabular}{lccccc}
\hline Items & Ensiling days & Control & $10 \%$ WHDG & $20 \%$ WHDG & $30 \%$ WHDG \\
\hline $\mathrm{DM}$ & 7 & $346.62 \pm 5.08^{\mathrm{aA}}$ & $332.69 \pm 9.67^{\mathrm{aB}}$ & $317.90 \pm 4.80^{\mathrm{aC}}$ & $305.98 \pm 1.34^{\mathrm{aD}}$ \\
$(\mathrm{g} / \mathrm{kg} \mathrm{FW})$ & 14 & $333.01 \pm 3.00^{\mathrm{abA}}$ & $321.28 \pm 7.30^{\mathrm{aB}}$ & $310.92 \pm 1.17^{\mathrm{abC}}$ & $300.41 \pm 1.16^{\mathrm{aD}}$ \\
& 30 & $318.95 \pm 11.03^{\mathrm{bA}}$ & $315.63 \pm 17.91^{\mathrm{aA}}$ & $300.16 \pm 8.36^{\mathrm{bAB}}$ & $288.45 \pm 5.00^{\mathrm{bB}}$ \\
$\mathrm{pH}$ value & 7 & $5.76 \pm 0.18^{\mathrm{aA}}$ & $4.38 \pm 0.12^{\mathrm{aB}}$ & $4.32 \pm 0.03^{\mathrm{aB}}$ & $4.20 \pm 0.03^{\mathrm{aB}}$ \\
& 14 & $5.09 \pm 0.14^{\mathrm{bA}}$ & $4.26 \pm 0.13^{\mathrm{aB}}$ & $4.15 \pm 0.06^{\mathrm{bB}}$ & $4.10 \pm 0.03^{\mathrm{bB}}$ \\
& 30 & $4.88 \pm 0.13^{\mathrm{bA}}$ & $4.44 \pm 0.01^{\mathrm{aB}}$ & $4.24 \pm 0.03^{\mathrm{aC}}$ & $4.19 \pm 0.06^{\mathrm{aC}}$ \\
Lactic acid & 7 & $22.70 \pm 4.24^{\mathrm{cC}}$ & $50.33 \pm 5.89^{\mathrm{aB}}$ & $62.34 \pm 2.53^{\mathrm{aA}}$ & $66.45 \pm 1.06^{\mathrm{aA}}$ \\
$(\mathrm{g} / \mathrm{kg} \mathrm{DM})$ & 14 & $39.42 \pm 6.03^{\mathrm{bC}}$ & $55.10 \pm 4.43^{\mathrm{aB}}$ & $64.45 \pm 6.40^{\mathrm{aAB}}$ & $65.89 \pm 5.70^{\mathrm{aA}}$ \\
& 30 & $56.29 \pm 2.42^{\mathrm{aBC}}$ & $52.53 \pm 5.27^{\mathrm{aC}}$ & $70.37 \pm 8.54^{\mathrm{aA}}$ & $64.11 \pm 5.04^{\mathrm{aAB}}$ \\
\hline
\end{tabular}

WHDG = Wet hulless-barley distillers' grains. Average means \pm standard deviations.

Values with different lower case letters show significant differences among ensiling days in the same treatment.

Values with different capital letters show significant differences among treatments in the same ensiling day $(\mathrm{p}<0.05)$. 
Table 3. Effect of adding WHDG on volatile fatty acid content of mixed silages of hulless-barley straw and tall fescue during ensiling

\begin{tabular}{lccccc}
\hline Items & Ensiling days & Control & $10 \%$ WHDG & $20 \%$ WHDG & $30 \%$ WHDG \\
\hline Acetic acid & 7 & $15.74 \pm 1.37^{\mathrm{bB}}$ & $23.31 \pm 2.55^{\mathrm{bA}}$ & $18.57 \pm 1.45^{\mathrm{cB}}$ & $17.07 \pm 1.63^{\mathrm{bB}}$ \\
$(\mathrm{g} / \mathrm{kg} \mathrm{DM})$ & 14 & $22.29 \pm 3.05^{\mathrm{aB}}$ & $49.10 \pm 6.65^{\mathrm{aA}}$ & $24.43 \pm 1.03^{\mathrm{bB}}$ & $25.13 \pm 3.03^{\mathrm{aB}}$ \\
& 30 & $18.01 \pm 0.89^{\mathrm{bC}}$ & $39.80 \pm 4.59^{\mathrm{aA}}$ & $28.36 \pm 1.49^{\mathrm{aB}}$ & $31.82 \pm 4.89^{\mathrm{aB}}$ \\
Propionic acid & 7 & $7.26 \pm 0.60^{\mathrm{aA}}$ & $0.33 \pm 0.18^{\mathrm{aB}}$ & $0.42 \pm 0.02^{\mathrm{bB}}$ & $0.54 \pm 0.11^{\mathrm{bB}}$ \\
$(\mathrm{g} / \mathrm{kg} \mathrm{DM})$ & 14 & $9.87 \pm 1.43^{\mathrm{aA}}$ & $0.38 \pm 0.21^{\mathrm{aB}}$ & $0.44 \pm 0.19^{\mathrm{bB}}$ & $0.59 \pm 0.20^{\mathrm{bB}}$ \\
& 30 & $8.20 \pm 2.42^{\mathrm{aA}}$ & $0.66 \pm 0.19^{\mathrm{aB}}$ & $1.44 \pm 0.18^{\mathrm{aB}}$ & $1.13 \pm 0.09^{\mathrm{aB}}$ \\
Butyric acid & 7 & $5.84 \pm 0.50^{\mathrm{aA}}$ & $0.70 \pm 0.13^{\mathrm{bB}}$ & $0.53 \pm 0.04^{\mathrm{aB}}$ & $0.38 \pm 0.06^{\mathrm{aB}}$ \\
(g/kg DM) & 14 & $7.63 \pm 2.05^{\mathrm{aA}}$ & $0.46 \pm 0.10^{\mathrm{bB}}$ & $0.44 \pm 0.26^{\mathrm{aB}}$ & $0.61 \pm 0.16^{\mathrm{aB}}$ \\
& 30 & $6.41 \pm 1.98^{\mathrm{aA}}$ & $1.28 \pm 0.16^{\mathrm{aB}}$ & $0.45 \pm 0.11^{\mathrm{aB}}$ & $0.89 \pm 0.50^{\mathrm{aB}}$ \\
Total VFAs & 7 & $28.84 \pm 0.28^{\mathrm{bA}}$ & $25.23 \pm 2.28^{\mathrm{bB}}$ & $20.03 \pm 1.41^{\mathrm{cC}}$ & $17.99 \pm 1.75^{\mathrm{cC}}$ \\
(g/kg DM) & 14 & $39.78 \pm 3.84^{\mathrm{aB}}$ & $50.33 \pm 6.88^{\mathrm{aA}}$ & $25.31 \pm 1.34^{\mathrm{bC}}$ & $26.33 \pm 3.20^{\mathrm{bC}}$ \\
Lactic acid & 30 & $32.61 \pm 5.16^{\mathrm{abB}}$ & $41.95 \pm 4.41^{\mathrm{aA}}$ & $31.25 \pm 1.46^{\mathrm{aB}}$ & $34.31 \pm 4.19^{\mathrm{aAB}}$ \\
$/$ Acetic acid & 7 & $1.43 \pm 0.16^{\mathrm{bD}}$ & $2.17 \pm 0.28^{\mathrm{aC}}$ & $3.36 \pm 0.12^{\mathrm{aB}}$ & $3.92 \pm 0.40^{\mathrm{aA}}$ \\
& 14 & $1.77 \pm 0.18^{\mathrm{bB}}$ & $1.14 \pm 0.18^{\mathrm{bC}}$ & $2.64 \pm 0.21^{\mathrm{bA}}$ & $2.66 \pm 0.52^{\mathrm{bA}}$ \\
\hline
\end{tabular}

WHDG = Wet hulless-barley distillers' grains. Average means \pm standard deviations.

Values with different lower case letters show significant differences among ensiling days in the same treatment.

Values with different capital letters show significant differences among treatments in the same ensiling day $(p<0.05)$.

Table 4. Effect of adding WHDG on WSC content and AN/TN of mixed silages of hulless-barley straw and tall fescue during ensiling

\begin{tabular}{lccccc}
\hline Items & Ensiling days & Control & $10 \%$ WHDG & $20 \%$ WHDG & $30 \%$ WHDG \\
\hline AN/TN & 7 & $163.88 \pm 8.43^{\mathrm{bA}}$ & $49.19 \pm 2.85^{\mathrm{bB}}$ & $43.21 \pm 1.58^{\mathrm{bB}}$ & $41.15 \pm 1.83^{\mathrm{bB}}$ \\
$(\mathrm{g} / \mathrm{kg} \mathrm{TN})$ & 14 & $169.02 \pm 3.47^{\mathrm{bA}}$ & $56.96 \pm 6.66^{\mathrm{abB}}$ & $48.25 \pm 2.70^{\mathrm{bC}}$ & $45.69 \pm 1.48^{\mathrm{bC}}$ \\
& 30 & $193.21 \pm 10.31^{\mathrm{aA}}$ & $61.41 \pm 7.09^{\mathrm{aB}}$ & $77.41 \pm 9.38^{\mathrm{abB}}$ & $69.87 \pm 7.99^{\mathrm{aB}}$ \\
WSC & 7 & $70.69 \pm 4.64^{\mathrm{aA}}$ & $44.86 \pm 3.83^{\mathrm{aB}}$ & $36.69 \pm 2.58^{\mathrm{aC}}$ & $34.05 \pm 1.57^{\mathrm{aC}}$ \\
$(\mathrm{g} / \mathrm{kg} \mathrm{DM})$ & 14 & $24.72 \pm 1.34^{\mathrm{bA}}$ & $22.65 \pm 3.43^{\mathrm{bA}}$ & $21.27 \pm 1.57^{\mathrm{bA}}$ & $21.30 \pm 5.43^{\mathrm{bA}}$ \\
& 30 & $13.27 \pm 0.95^{\mathrm{cB}}$ & $18.28 \pm 5.11^{\mathrm{bA}}$ & $17.70 \pm 0.35^{\mathrm{cAB}}$ & $18.26 \pm 0.41^{\mathrm{Ba}}$ \\
\hline
\end{tabular}

WHDG $=$ Wet hulless-barley distillers' grains. Average means \pm standard deviations.

Values with different lower case letters show significant differences among ensiling days in the same treatment.

Values with different capital letters show significant differences among treatments in the same ensiling day $(\mathrm{p}<0.05)$.

WSC content than WHDG-containing silages, however, this difference was reversed by the end of the ensiling period $(\mathrm{p}<0.05)$.

The chemical compositions of the silages after $30 \mathrm{~d}$ of ensilage are presented in Table 5. The addition of WHDG to silage resulted in a significant increase $(p<0.05)$ in $C P$ contents, with the silage containing $30 \%$ WHDG having the highest CP content, however, when the inclusion level of WHDG increased from $10 \%$ to $20 \%$ there was no effect ( $>0.05$ ) on the CP content of the silage. While WHDG addition tended to decrease NDF and ADF content of mixed silages $(p>0.05)$, silage containing $30 \%$ WHDG had the lowest NDF content $(\mathrm{p}<0.05)$ and when the inclusion level of WHDG was above $20 \%$ the ADF content was significantly higher $(\mathrm{p}<0.05)$ than that of the control.

\section{DISCUSSION}

After $30 \mathrm{~d}$ of ensiling, the $\mathrm{pH}$ of silages containing 10 or $20 \%$ WHDG was not below 4.2 , which is a target $\mathrm{pH}$ for

Table 5. The chemical composition of mixed silage of hulless-barley straw and tall fescue after 30 days ensiling

\begin{tabular}{lclll}
\hline Item & \multicolumn{1}{c}{ Control } & $10 \%$ WHDG & $20 \%$ WHDG & $30 \%$ WHDG \\
\hline Crude protein (SD) (g/kg DM) & $88.97 \pm 2.93^{\mathrm{C}}$ & $103.41 \pm 1.00^{\mathrm{B}}$ & $106.43 \pm 1.09^{\mathrm{B}}$ & $114.62 \pm 2.37^{\mathrm{A}}$ \\
$\mathrm{NDF}(\mathrm{SD})(\mathrm{g} / \mathrm{kg} \mathrm{DM})$ & $607.46 \pm 23.56^{\mathrm{A}}$ & $599.14 \pm 2.72^{\mathrm{A}}$ & $579.60 \pm 7.30^{\mathrm{A}}$ & $539.46 \pm 18.49^{\mathrm{B}}$ \\
$\mathrm{ADF}(\mathrm{SD})(\mathrm{g} / \mathrm{kg} \mathrm{DM})$ & $361.70 \pm 9.39^{\mathrm{A}}$ & $338.58 \pm 6.96^{\mathrm{AB}}$ & $328.17 \pm 31.37^{\mathrm{B}}$ & $316.21 \pm 11.09^{\mathrm{B}}$ \\
\hline
\end{tabular}

WHDG = Wet hulless-barley distillers' grains. Average means \pm standard deviations.

Values with different capital letters show significant differences among treatments $(\mathrm{p}<0.05)$. 
well-preserved silage, however, this critical $\mathrm{pH}$ value varies with moisture content (McDonald et al., 1991). According to Weissbach (1996), when the DM content of an ensiled crop was $320 \mathrm{~g} / \mathrm{kg}$, a $\mathrm{pH}$ of 4.53 could ensure effective preservation. Meeske et al. (2002) also reported that oat silages were well preserved at a $\mathrm{pH}$ of 4.56 and 4.52 when the DM was 317 and $328 \mathrm{~g} / \mathrm{kg}$, respectively. In this study, the DM content of the WHDG-containing silages was above $303.01 \mathrm{~g} / \mathrm{kg}$, and the $\mathrm{pH}$ value of these silages was lower than 4.4 , while that of control silage was 4.88 , suggesting that the WHDG-containing silages had effective preservation. Other indicators of effective preservation include AN being less than $100 \mathrm{~g} / \mathrm{kg} \mathrm{TN}$ (Haigh and Hopkins, 1977), butyric acid lower than $10 \mathrm{~g} / \mathrm{kg} \mathrm{DM}$ (Nilsson and Nilsson, 1956), and an efficient conversion of WSC to lactic acid (Parker and Crawshaw, 1982). On the basis of these parameters the mixed silages containing WHDG were well preserved, especially the silages containing 20 or $30 \%$ WHDG.

The DM contents of the WHDG-containing silages were significantly lower compared with the control and decreased as the inclusion rate of WHDG increased $(\mathrm{p}<0.05)$. This was due to the high moisture content of WHDG.

At $7 \mathrm{~d}$ of ensiling, the $\mathrm{pH}$ value of all the WHDGcontaining silages was lower than 4.38 , while that of the control silage was still 5.76. Correspondingly, the LA concentration of the WHDG-containing silages was significantly higher $(\mathrm{p}<0.05)$ than that of the control silage. After 7 d, WHDG-containing silages reached a stable condition, with the $\mathrm{pH}$ value and the LA concentration remaining almost unchanged until the fermentation was terminated at $30 \mathrm{~d}$. The WHDG-containing silages showed more extensive fermentation than the control silage, especially during the first $7 \mathrm{~d}$ of ensiling. Although there was a gradual increase in LA concentrations in the control silage after $7 \mathrm{~d}$ of ensiling, the $\mathrm{pH}$ value and LA concentrations remained significantly different $(\mathrm{p}<0.05)$ between the control silage and $20 \%$ or $30 \%$ WHDGcontaining silages. This indicated that WHDG addition accelerated the onset of LA fermentation. There may be several reasons for this. The inclusion of WHDG would have a dual action in the mixed silage. Firstly, there were large amounts of $\mathrm{O}_{2}$ trapped in silos and aerobic bacteria could dominate the fermentation during the initial period of ensiling, however, residual ethanol contained in WHDG not only inhibited the activity of undesirable (aerobic) microorganisms, but also accelerated the onset of LA fermentation. On the other hand, the higher moisture content contained in WHDG also could stimulate the growth of LA-producing bacteria and accelerate the rate of fermentation. Zhang et al. (2011) reported that ethanol addition could inhibit the activity of aerobic microorganisms and depress the losses of WSC during early stages of ensiling and result in more WSC for LA production in elephant grass silage. This result is also consistent with the reports of Ridla and Uchida (1994), who observed that fermentation was stimulated and rapidly achieved acid condition by mixing barley straw with wet brewers' grains.

The concentration of AA increased with the ensiling period, and the ratio of LA/AA tended to decline in the WHDG-containing silages after $7 \mathrm{~d}$ of ensiling. This indicated that the fermentation pattern was changed from homofermentation to heterofermentation and is in agreement with other studies as reported by Shao et al. (2002; 2005), who found that there was a significant shift from homofermentative to heterofermentative activity after $5 \mathrm{~d}$ of ensiling. McDonald et al. (1991) also reported that in well-preserved silages, acidification was initiated by homofermentative strains, but after only $4 \mathrm{~d} 85 \%$ of the strains were heterofermentative, whose tolerance to acetic acid was greater than homofermentative strains. The WHDG-containing silages showed somewhat $(\mathrm{p}>0.05)$ or significantly $(\mathrm{p}<0.05)$ higher AA concentrations as compared with the control silage, with the silage containing $10 \%$ WHDG having the highest AA concentrations throughout the ensiling period $(p<0.05)$. This may be explained as follows. WHDG probably contained some AAproducing bacteria, the majority of which were aerobes. These microbes can utilize fructose and glucose as energy sources via the phosphate pentose pathway, with acetaldehyde as an intermediate, producing acetic acid before complete exhaustion of fresh air from the silage mass (McDonald et al., 1991). However, ethanol could inhibit the activity of aerobic microorganism (including AA-producing bacteria), and these effects may become more pronounced as the proportion of WHDG increased in the silage mixture.

The ratio of AN/TN in silages indicated the extent of proteolysis. Kemble (1956) reported that proteolysis began immediately at harvest, with the majority occurring during the first week of ensiling. Our observations are consistent with this, the proteolysis-inhibited effect of WHDG in the silage mixtures was pronounced during the ensiling especially the initial stages of ensiling. It is generally recognized that protein is degraded into amino acids by microorganisms and plant enzymes, and further broken down into ammonia or amines, resulting in a loss of silage protein. In the present study, the ratio of AN/TN in the WHDG-containing silages was significantly lower than the control silage after $7 \mathrm{~d}$. This may be due to ethanol contained in WHDG inhibiting the degradation of protein by aerobic bacteria during the early stages of ensiling. Zhang et al. (2011) found that ethanol could act as a silage fermentation inhibitor to effectively reduce the ammonia-N 
content of silage. The significant difference of butyric acid concentration between WHDG-containing and the control silages also indicated that the activity of clostridial organisms (which produce butyric acid) was inhibited by residual ethanol of WHDG. Chiou et al. (2000) also reported that including wet sorghum distillers' grains in silage made from Napier grass significantly lowered ammonia-N and butyric acid concentration as compared to the control.

The content of residual WSC in WHDG-containing silages was significantly lower than that of the control silage, and declined with the increasing levels of WHDG within $7 \mathrm{~d}$ of ensiling. This indicated that the WHDGcontaining silages had more extensive fermentation than the control silage during the first $7 \mathrm{~d}$ of ensiling, and more WSC was consumed by the LA-producing bacteria. This result is consistent with higher concentrations of LA in the WHDG-containing silages. Ultimately, the concentrations of WSC and LA were significantly higher in the silages containing 10 and 30\% WHDG as compared to the control silage indicating that WHDG improved the transformation of WSC to LA and AA. This may have been due to residual ethanol contained in WHDG depressing the loss of WSC consumed by undesirable bacteria, so that more residual WSC was present in the final silages resulting in a greater amount of substrate available for LA-producing bacteria. This is in agreement with Ohba et al. (2002), who observed that $3 \%$ ethanol promoted a more efficient fermentation, as indicated by a faster $\mathrm{pH}$ decline, higher concentration of LA and residual WSC. Chiou et al. (2000) also demonstrated that increased levels of inclusion of wet sorghum distillers' grains in Napier grass silage not only increased the WSC content but also increased the titratable acidity, providing a better fermentation environment for LA-production bacteria.

The difference between the control and WHDGcontaining silages with regard to chemical composition depended on the chemical characteristics of the WHDG added. The significantly higher $\mathrm{CP}$ concentrations in the WHDG-containing silages compared with the control silage are consistent with the inclusion of WHDG, which is higher in CP than hulless-barley straw and tall fescue. The addition of WHDG to mixed silage resulted in decreased ADF and NDF contents, due to the low ADF and NDF content in WHDG. These results are in agreement with Ridla and Uchida (1994) who found significant increase in silage CP content and reduction in fibrous components with increasing proportion of wet brewers' grains.

\section{CONCLUSIONS}

In conclusion, in this study WHDG inclusion accelerated the initiation LA fermentation and inhibited the activity of aerobic bacteria, which could compete with desirable LA-producing bacteria for WSC and protein. The addition of WHDG not only improved fermentation quality of mixed silage of hulless-barley straw and tall fescue, but also increased their $\mathrm{CP}$ content and decreased the ADF and NDF contents. Therefore, addition of WHDG to mixed silage of hulless-barley straw and tall fescue can be a good approach toward solving the forage shortage during the insufficiency periods of forage in Tibet.

\section{ACKNOWLEDGEMENTS}

This work was supported by the grant for key techniques research in straw-grass mixed silage from Tibet (XZ20093ZD) and the grant of National "12th Five-Year" Plan for Science and Technology Support project: Comprehensive treatment key technology and demonstration project of the Degraded grassland in north Tibetan Plateau (2010BAE00739-03).

\section{REFERENCES}

Anderson, J. L., K. F. Kalscheur, A. D. Garcia, D. J. Schingoethe and A. R. Hippen. 2009. Ensiling characteristics of wet distillers grains mixed with soybean hulls and evaluation of the feeding value for growing Holstein heifers. J. Anim. Sci. 87(6):2113-2123.

AOAC. 1984. Official methods of Analysis. 14th ed., Association of Official and Analytical Chemists, Arlington, Virginia, USA.

Barker, S. B. and W. H. Summerson. 1941. The colorimetric determination of lactic acid in biological material. J. Biol. Chem. 138:535-554.

Broderick, G. A. and J. H. Kang. 1980. Automated simultaneous determination of ammonia and total amino acids in ruminal fluid and in vitro media. J. Dairy Sci. 63(1):64-75.

Cao, Y., Y. Cai, T. Hirakubo, H. Fukui and H. Matsuyama. 2011. Fermentation characteristics and microorganism composition of total mixed ration silage with local food by-products in different seasons. Anim. Sci. 82(2):259-266.

Chiou, P. W. S., S. H. Chang and B. Yu. 2000. The effects of wet sorghum distillers' grains inclusion on napiergrass silage quality. J. Sci. Food Agric. 80(8):1199-1205.

Duan, Y. H., Z. F. Tan, Y. P. Wang, Z. W. Li, Z. Y. Li, G. Y. Qin, Y. P. Huo and Y. M. Cai. 2008. Identification and characterization of lactic acid bacteria isolated from Tibetan Qula cheese. J. Gen. Appl. Microbiol. 54(1):51-60.

Haigh, P. M. and J. R. Hopkins. 1977. Relationship between oven and toluene dry matter in grass silage. J. Sci. Food Agric. 28(6):477-480.

Kemble, A. R. 1956. Studies on the nitrogen metabolism of the ensilage process. J. Sci. Food Agric. 7(2):125-130.

Krishnamoorthy, U., T. V. Muscato, C. J. Sniffen and P. J. Van Soest. 1982. Nitrogen fractions in selected feedstuffs. J. Dairy Sci. 65(2):217-225.

McDonald, P., A. R. Henderson and S. J. E. Heron. 1991. The biochemistry of silage. 2th ed., Cambrian Printers Ltd, Aberystwyth.

Meeske, R., G. D. van der Merwe, J. F. Greyling and C. W. 
Cruywagen. 2002. The effect of adding an enzyme containing lactic acid bacterial inoculant to big round bale oat silage on intake, milk production and milk composition of Jersey cows. Anim. Feed Sci. Technol. 97(3-4):159-167.

Nilsson, G. and P. E. Nilsson. 1956. Silage studies. IV. The microflora on the surface of some fodder plants at different stages of maturity. Arch. Microbiol. 24(4):412-422.

Nishino, N., H. Hiroaki and E. Sakaguchi. 2003. Evaluation of fermentation and aerobic stability of wet brewers' grains ensiled alone or in combination with various feeds as a total mixed ration. J. Sci. Food Agric. 83(6):557-563.

Ohba, N., M. Tobisa and M. Shimojo. 2002. Effect of ethanol addition on ensiling of forage oats and italian ryegrass. Sci. Bull Faculty Agric. Kyushu Univ. 57:11-15.

Parker, J. W. G. and R. Crawshaw. 1982. Effects of formic acid on silage fermentation, digestibility, intake and performance of young cattle. Grass Forage Sci. 37(1):53-58.

Ridla, M. and S. Uchida. 1994. Fermentation quality and silage additives value of barley straw and wet brwers'grains silage. Asian-Aust. J. Anim. Sci. 7:517-522.

SAS. 1999. SAS/STAT user's guide: (Version 8.01th ed), SAS Institute Inc., Cary, North Carolina, USA.

Shao, T., N. Ohba, M. Shimojo and Y. Masuda. 2002. Dynamics of early fermentation of Italian ryegrass (Lolium multiflorum Lam.) silage. Asian-Aust. J. Anim. Sci. 15:1606-1610.
Shao, T., Z. X. Zhang, M. Shimojo, T. Wanga and Y. Masuda. 2005. Comparison of fermentation characteristics of italian ryegrass (Lolium multiflorum Lam.) and guineagrass (Panicum maximum Jacq.) during the early stage of ensiling. Asian-Aust. J. Anim. Sci. 18:1727-1734.

Suksombat, W. 2004. Silage from agricultural by-products in Thailand: processing and storage. Asian-Aust. J. Anim. Sci. 17:473-478.

Thomas, T. A. 1977. An automated procedure for the determination of soluble carbohydrates in herbage. J. Sci. Food Agric. 28(7):639-642.

Titterton, M. and B. V. Maasdorp. 1997. Nutritional improvement of maize silage for dairying: mixed crop silages from sole and intercropped legumes and a long season variety of maize. 2. Ensilage. Anim. Feed Sci. Technol. 69(1-3):263-270.

Van Soest, P. J., J. B. Robertson and B. A. Lewis. 1991. Methods for dietary fiber, neutral detergent fiber, and nonstarch polysaccharides in relation to animal nutrition. J. Dairy Sci. 74(10):3583-3597.

Weissbach, P. J. 1996. New developments in crop preservation, In: Proceedings of 11th International Silage Conference, Aberystwyth.

Zhang, L., C. Q. Yu, M. Shimojo and T. Shao. 2011. Effect of different rates of ethanol additive on fermentation quality of napiergrass (pennisetum purpureum). Asian-Aust. J. Anim. Sci. 24:636-642. 